\title{
PERANCANGAN SISTEM INFORMASI AKUNTANSI PEMBELIAN STUDI KASUS : UD XYZ SALATIGA
}

\author{
Purwanto $^{1)}$ \\ 1) Komputerisasi Akuntansi, FTI-UKSW \\ ${ }^{1)}$ purwanto@uksw.edu
}

\begin{abstract}
The objective of the company's business activities is to give gain or profit. One of the ways to meet the objective is by reducing the cost. The company which does not regulate its purchases will suffer losses. The purpose of the study was to design a purchasing accounting information system to assist in increasing company profits. The research methods were by defining and analyzing system requirements by using Data Flow Diagrams (DFD), Resouces Events Agent (REA), Form Design, Information System Implementation. The result of the study was that the purchasing accounting information system had answered the company's needs in terms of: 1. time effectiveness on recapitulating the purchased order data, 2. Minimizing errors occured in the type and amount of goods to be purchased.
\end{abstract}

Keywords : system design, purchasing, accounting system, information system

\section{PENDAHULUAN}

Tujuan utama perusahaan menjalankan aktivitas bisnis adalah mendapatkan keuntungan atau laba. Perhitungan Laba didapat dari jumlah pendapatan perusahaan dikurangi dengan jumlah biaya perusahaan. Salah strategi untuk menaikkan laba perusahaan adalah menurunkan biaya dimana pendapatan tetap atau menaikkan pendapatan dimana biaya tetap. Menurut Michael E. Porter (Mindtools) mengatakan bahwa perusahaan perlu memiliki value added chain jika perusahaan ingin bersaing dengan perusahaan lain. Value added chain melihat bisnis sebagai rantai aktifitas yang mengubah dari input menjadi output yang memiliki nilai bagi pemakai akhir. Value added chain terbagi menjadi 2 bagian yaitu primary activities dan support activities. Primary activities terdiri dari inbound logistics, operations, outbond logistics, marketing and sales, service. Sedangkan untuk supporting activities terdiri dari Firm Infrastructure, Human Resources Management, Research-Technology and System Development, procurement. Pada dasarnya perusahaan sudah dapat menjalankan aktivitas bisnis minimal memiliki fungsi primary activities tanpa harus menerapkan fungsi supporting activities. Akan tetapi akan menjadi lebih bernilai jika perusahaan juga menerapkan support activities. (The Mind Tools Content Team, 2010)

Pembelian merupakan salah satu dari fungsi supporting activities. Dampak penanganan pembelian yang kurang baik akan merugikan perusahaan yaitu naiknya nilai biaya pembelian atau harga pokok pembelian. Ketika biaya pembelian atau harga pokok pembelian meningkat dan dimana pendapatan tetap maka perusahaan akan mengalami kerugian. Pencatatan transaksi pembelian barang secara manual dapat menambah besarnya kerugaian perusahaan ketika transaksi perusahaan sudah banyak. Untuk menghindari hal tersebut perusahaan dapat menggunakan teknologi informasi sehingga pembelian dapat ditangani lebih baik. Pembelian yang ditangani dengan baik dan menggunakan teknologi informasi akan menghasilkan hasil yang lebih baik dalam mengendalikan biaya pembelian sehingga laba perusahan dapat meningkat. 
UD XYZ Salatiga merupakan perusahaan dagang yang bergerak dalam bidang penjualan dan distribusi Sayur Organik. Wilayah pemasaranya adalah beberapa kota di Indonesia seperti Salatiga, Semarang, Solo, Yogjakarta, Surabaya, Bandung, Bekasi dan lain-lain. Selain itu UD XYZ Salatiga menjadi pemasok toko-toko di wilayah Jawa Tengah \& Jawa Barat. Pekerjaan pembelian merupakan pekerjaan yang sering berulang yaitu merekapitulasi pesanan pelanggan reguler dan juga pelanggan toko kemudian memesankan barang ke para petani. Apabila jumlah pesanan semakin banyak maka akan membutuhkan banyak waktu dalam menyiapkan daftar pesanan, akan ada kesalahan dalam memilih petani yang tetap dan terdapat kesalahan jumlah barang yang dipesan. Maka dari itu penting sekali untuk melakukan perancangan sistem informasi akuntansi pembelian pada UD XYZ Salatiga.

\section{TINJAUAN PUSTAKA}

Pembelian adalah suatu usaha yang digunakan dalam perusahaan untuk pengadaan barang yang diperlukan oleh perusahaan. (Indrajani, 2015) Mudjahidin menulis tentang siklus bisnis pada Sistem Informasi Akuntansi terdiri dari Siklus Pendapatan, Siklus Pengeluaran, Siklus Produksi, Siklus Manajemen SDM/Penggajian dan Sistem Buku Besar/Pelaporan. (Mudjahidin, 2004) Siklus utama perusahaan yaitu 1. Acquisition (purchasing Cycle) yang mengacu pada pembelian barang dan jasa, 2. Conversion cycle mengacu pada proses mengubah sumber daya baik bahan baku maupun manusia menjadi suatu produk barang jadi atau jasa, 3. Revenue cycle mengacu pada proses penyediaan barang jadi dan jasa kepada pelanggan. Fungsi-fungsi yang terkait dalam siklus pengeluaran yaitu : 1. Inventory Management/Logistic bertujuan untuk mengelola persediaan barang dagang yang didapatkan oleh perusahaan untuk dijual kembali. 2 . Finance/Accounting berhubungan dengan pembiayaan, data informasi, perencanaan dan pengendalian terhadap sumber daya.(Purwoko, 2010) Menurut Indrajani fungsi pembelian bertanggung jawab untuk memperoleh informasi mengenai harga barang, menentukan pemasok yang dipilih dalam pengadaan barang, dan mengeluarkan pesanan pembelian kepada pemasok yang dipilih. (Indrajani, 2015) Tahapan-tahapan proses transaksi sistem informasi akuntansi pembelian adalah 1. Melakukan konsultasi dengan pemasok sebelum membeli. 2. Proses permintaan. 3. Mengadakan perjanjian dengan pemasok. 4. Penerimaan barang. 5. Pengecekan penerimaan barang. 6. Pembayaran. (Purwoko, 2010)

Penelitian Purwoko tentang Perancangan Sistem Informasi Akuntansi Pembelian dan Persediaan Pada PT ABC menggunakan metodologi library research dan field research, sedangkan untuk metodologi analiysis dan perancangan menggunakan Object Oriented Analysis dan Design. Rancangan yang dihasilkan adalah Use Case proses pembelian dan persediaan, Class Diagram, User Interface, Konfigurasi Sistem. Hasil penelitian mengatakan sistem terkomputerisasi dapat membantu pihak manajemen dalam mengurangi kesalahan dan meningkatkan efektivitas sistem yang ada. (Purwoko, 2010)

Hanny Juwitasari dkk menulis penelitian mengenai Analisis Sistem Informasi Akuntansi Pembelian dan Persediaan pada PT XYZ menggunakan metodologi penelitian survei terhadap proses bisnis perusahaan, studi literature dengan metode Analisis dan Perancangan sistem informasi Orientasi Objek (OOAD). Penelitian menghasilkan rancangan Use Case proses pembelian dan persediaan, Class Diagram proses pembelian dan persediaan, User Interface. Perencanaan persediaan diperlukan untuk memenuhi rencanan produksi dan untuk menentukan kapan pemesanan harus dilakukan kembali, pengamanan persediaan. Dengan Sistem Informasi Akuntansi Pembelian dan Persediaan 
diharapkan membantu perusahaan dalam meningkatkan sistem pengendalian internal yang baik. (Hanny Juwitasary, Marlene Martani, 2015)

Sedangkan peneliti ini tertarik untuk merancangan Sistem Informasi Akuntansi pembelian dengan berdasarkan order penjualan pada UD XYZ Salatiga. Metode penelitian menggunakan Waterfall, Rancanan Desain dengan menggunakan Data Flow Diagram, Resources Events Agen, Rancangan Form serta Implementasi kedalam User Interface.

\section{METODE PENELITIAN}

Metode penelitian yang digunakan adalah metode analisis pengumpulan data dan perancangan sistem. Data yang digunakan adalah data primer dan data sekunder dari UD XYZ Salatiga. Pengumpulan Data melalui wawancara kepada pemilik perusahaan dan para pegawai yang terlibat dalam sistem pembelian serta melakukan pengamatan kegiatan bisnis pada UD XYZ Salatiga terhadap sistem yang sedang berjalan sehingga mendapatkan data mengenai kebutuhan informasi khususnya kegiatan pembelian dari perusahaan.

Langkah penelitian dengan menggunakan model waterfall yaitu : 1 . Pendefinisian dan analisis kebutuhan : mengumpulkan kebutuhan secara lengkap sistem pembelian pada UD XYZ Salatiga dari penerimaan order penjualan baik dari pelanggan reguler maupun dari toko sampai bagian pembelian menghasilkan rekapitulasi pesanan per pemasok atau petani. 2. Desain sistem informasi : mendesain sistem secara keseluruhan berdasarkan hasil analisis kebutuhan, desain Data Flow Diagram (DFD), desain Resouces Events Agent (REA), Rancangan Form. 3. Implementasi sistem: membangun sistem berdasarkan desain yang telah dibuat. 4. Integrasi dan pengujian: melakukan pengintegrasian sistem dan melakukan pengujian sistem secara keseluruhan. 5. Pemeliharaan : mengoperasikan dan memelihara sistem yang telah terbentuk. Dalam penelitian ini tahapan yang dilakukan hanya sampai pada tahap ke 3 .

\section{HASIL DAN PEMBAHASAN}

Berdasarkan wawancara dan mempelajari kegiatan bisnis UD XYZ Salatiga, sistem pembelian dapat dituangkan dalam bentuk prosedur sebagai berikut :

1. Transaksi bisnis dimulai dari bagian penjualan menerima pesanan penjualan dari pelanggan atau toko melalui aplikasi whastapp/SMS.

2. Bagian penjualan mencatat semua pesanan penjualan ke dalam buku penjualan bersasarkan nama pelanggan dan tanggal pengiriman serta mengecek apakah transaksi sudah terbayar atau belum? Jika sudah maka bagian penjualan memberi tanda sudah terbayar pada buku penjualan, jika belum maka bagian penjualan menghubungi Pelanggan. Bagian penjualan membuat nota penjualan bedasarkan pesanan dan buku penjualan.

3. Bagian Pembelian meminjam buku penjualan dan membuat rekapitulasi data barang berdasarkan tanggal.

4. Bagian pembelian menghubungi pemasok/petani untuk memesankan barang berdasarkan rekapitulasi data barang. Rekapitulasi data barang diberikan kepada bagian penerimaan barang.

5. Bagian penerimaan barang mengecek barang yang dikirim oleh pemasok/petani berdasarkan rekapitulasi data barang.

Berdasarkan prosedur diatas maka bagian yang terlibat dalam sistem pembelian adalah bagian penjualan, bagian pembelian, bagian penerimaan barang. Dokumen yang dipakai dalam sistem pembelian adalah nota penjualan, sedangkan catatan yang dipakai dalam sistem pembelian adalah buku penjualan, rekapitulasi data barang. Penulis melihat terdapat 
kelemahan pada sistem pembelian UD XYZ Salatiga yaitu jika jumlah pelanggan yang melakukan transaksi banyak maka kebutuhan waktu dalam membuat rekapitulasi data barang sangat banyak, selain itu juga dapat memungkinkan terjadi kesalahan dalam melakukan rekpitulasi data barang khususnya untuk data jenis dan jumlah pesanan.

Penulis melihat bahwa perusahaan memerlukan sistem terkomputerisasi, dimana sistem terkomputerisasi dapat menjawab : 1 . Sistem dapat menampung data penjualan pelanggan. 2. Sistem komputerisasi dapat membantu perusahaan dalam menghasilkan rekapitulasi data pesanan pembelian ke pemasok atau petani per tanggal pengiriman baik secara seluruhnya maupun berdasarkan pelanggan. Prosedur sistem informasi akuntansi pembelian dapat desain sebagai berikut :

1. Bagian penjualan menerima pesanan penjualan dari pelanggan atau toko melalui aplikasi whastapp/SMS atau pelanggan dapat membuat pesanan sendiri melalui sistem informasi.

2. Bagian Penjualan menginputkan semua pesanan penjualan ke dalam sistem informasi bersasarkan nama pelanggan dan tanggal pengiriman. Bagian penjualan mengecek apakah pesanan tersebut sudah terbayar atau belum? Jika sudah terbayar maka Bagian Penjualan memberi tanda pada nota penjualan sudah terbayar, jika belum terbayar maka bagian penjualan menghubungi pelanggan. Bagian penjualan mencetak nota penjualan melalui sistem informasi.

3. Bagian pembelian membuat rekapitulasi data barang dengan menggunakan sistem informasi berdasarkan tanggal kirim.

4. Bagian pembelian menghubungi pemasok/petani untuk memesankan barang berdasarkan hasil rekapitulasi data barang.

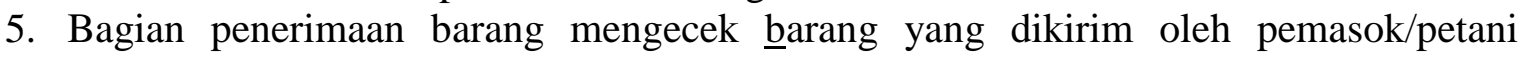
berdasarkan hasil rekapitulasi data barang.

Berdasarkan prosedur diatas maka desain sistem informasi dimulai dengan pembuatan DFD Context diagram, DFD Level 0. Dalam DFD terdiri dari 2 agen eksternal yaitu prosedur penjualan dan Pemasok/petani, 1 proses sistem informasi akuntansi pembelian serta beberapa arus data. Gambar DFD sistem informasi akuntansi pembelian UD XYZ Salatiga dapat dilihat pada Gambar 1.

Setelah membuat Context Diagram maka selanjutnya adalah membuat DFD level 0 dengan dekomposisi fungsi sebagai berikut: proses 1.0 Memastikan order penjualan, poses 2.0 Rekapitulasi pesanan. Gambar diagram level 0 sistem informasi akuntansi pembelian UD XYZ Salatiga dapat dilihat pada Gambar 2. Proses 1.0 dapat di jabarkan lagi dengan proses 1.1 Cetak nota dan proses 1.2 Cetak nota pertanggal kirim sedangkan untuk proses 2.0 dapat dijabarkan menjadi proses 2.1 Laporan rekap sayur dan proses 2.2 Laporan Detail Pembelian Sayur. Gambar diagram level 1 sistem informasi akuntansi pembelian dapat dilihat pada gambar 3.

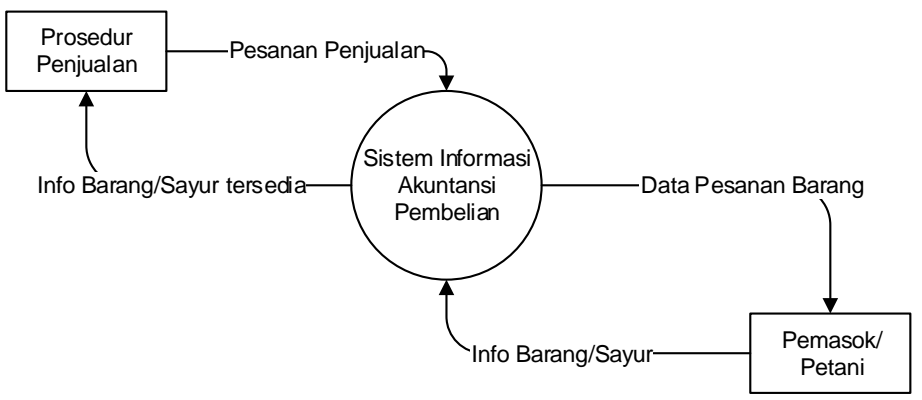

Gambar 1. Context diagram 


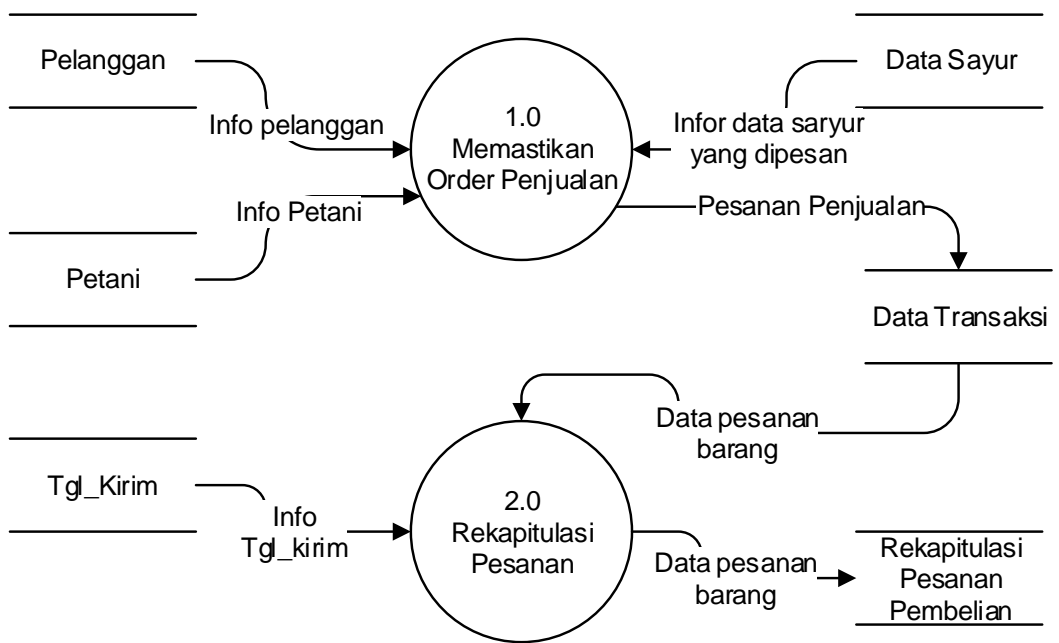

Gambar 2. Dfd level 0 sistem informasi akuntansi pembelian UD XYZ Salatiga

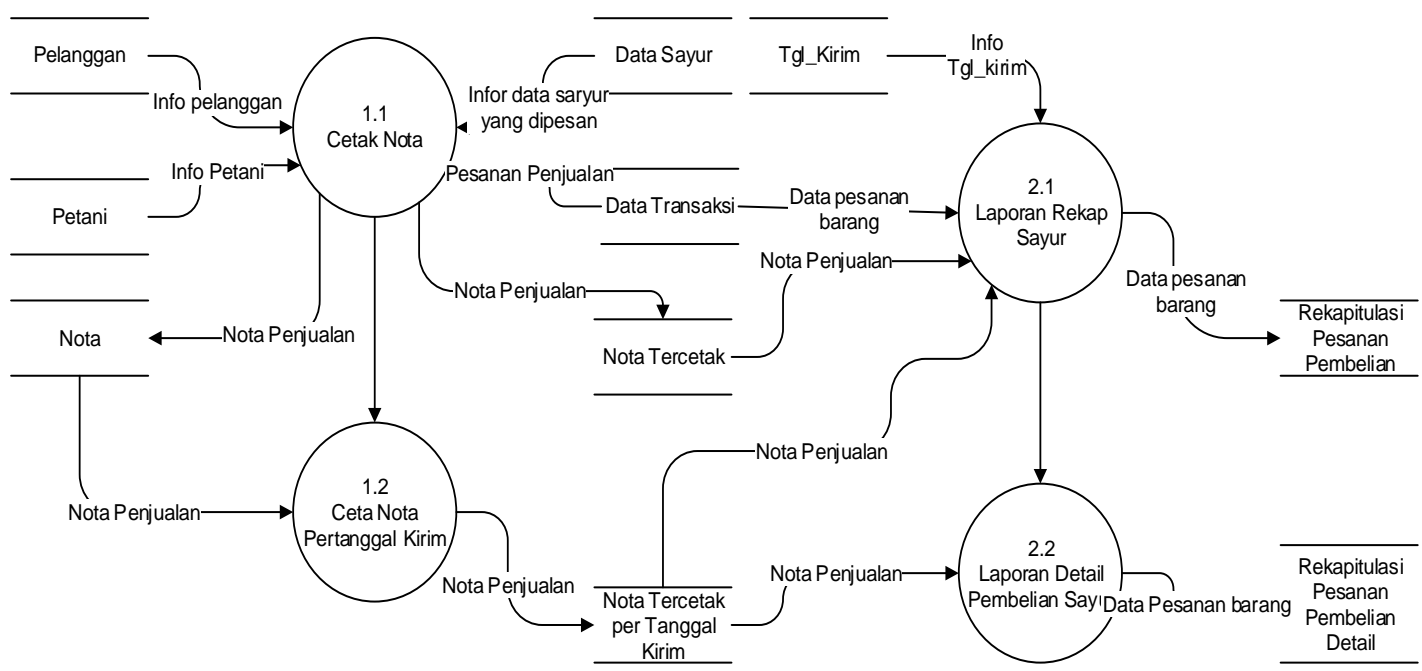

Gambar 3. Dfd level 1 sistem informasi akuntansi pembelian UD XYZ Salatiga

Langkah rancangan sistem informasi akuntansi pembelian berikutnya adalah rancangan desain Resouces Events Agent (REA) berdasarkan hasil data yang telah didapat. REA yang dibuat terdiri dari Resouces yaitu entitas Sayur serta Tanggal_kirim, untuk Events yaitu Transaksi dan untuk Agent yaitu Pelanggan serta Petani. Gambar REA Sistem Informasi Akuntansi Pembelian dapat dilihat pada Gambar 4.

$$
\text { Resouces Agent }
$$

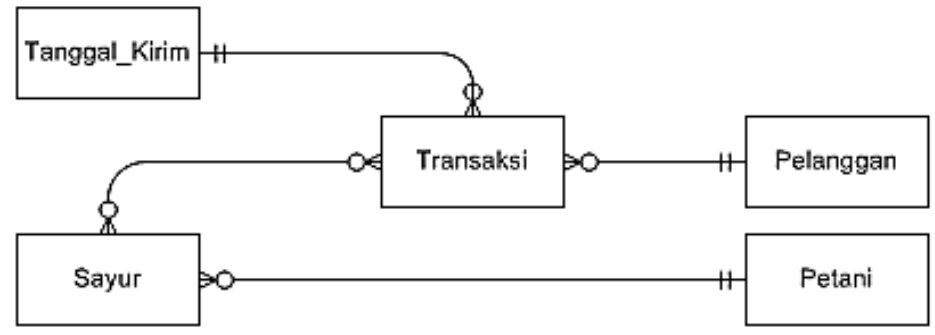

Gambar 4. Rea sistem informasi akuntansi pembelian UD XYZ Salatiga 
Entitas Transaksi berhubungan dengan entitas Sayur dengan hubungan many to many maka perlu dibuatkan satu entitas lain yaitu detail_transaksi, sehingga gambar REA menjadi seperti Gambar 5.

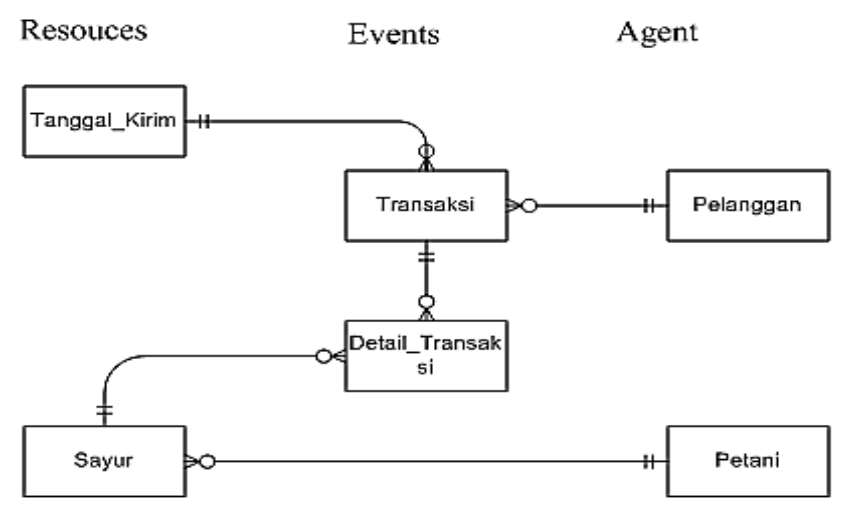

Gambar 5. Rea sistem informasi akuntansi pembelian UD XYZ Salatiga

REA yang terbentuk ditambahkan dengan keybase, yang berisi Primary Key (PK) dan Foreign Key (FK). Tampilan REA dengan keybase dapat dilihat pada Gambar 6. Desain REA dengan keybase ditambahkan field yang diperlukan untuk menampung kebutuhan informasi perusahaan. REA dengan full atribut dirancang databasenya menggunakan Mysql. Tampilan Gambar 7. merupakan contoh tampilan entitas transaksi dan detail transaksi dari REA Full atribut.

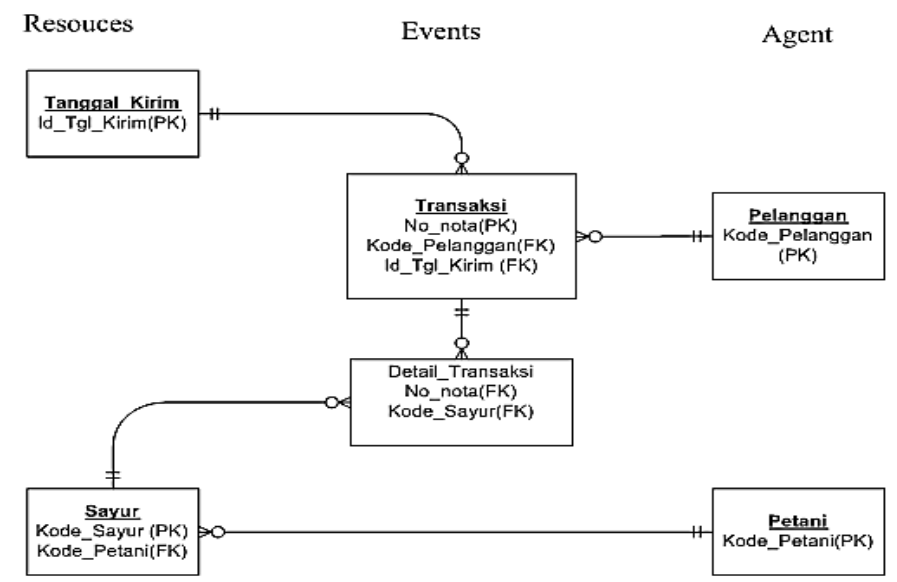

Gambar 6. Keybase sistem informasi akuntansi pembelian UD XYZ Salatiga
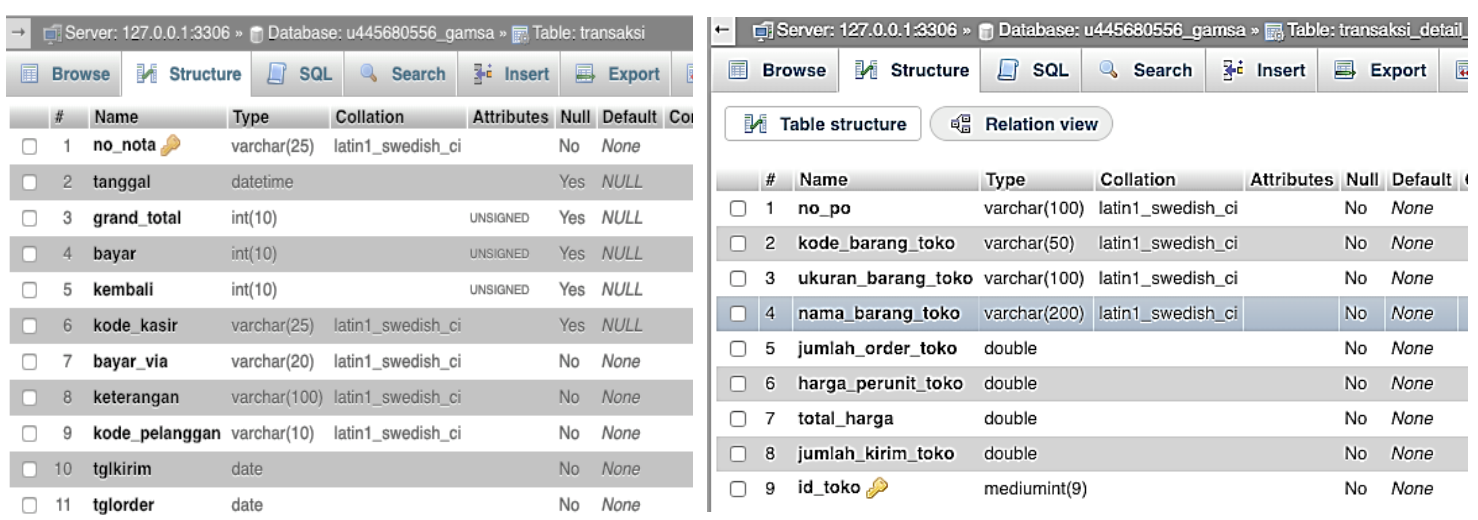

Gambar 7. Tampilan database pada mysql 
Desain dan perancangan sistem informasi akuntansi pembelian UD XYZ Salatiga diimplementasikan dengan aplikasi berbasis web. Tampilan implementasi form yang dibuat seperti pada Gambar 8 sampai Gambar 13. Rancangan implementasi pada aktivitas 1.0 Memastikan order penjualan dengan menu transaksi yang terdiri dari cetak nota dan cetak nota per tanggal. Gambar 8 menunjukkan tampilan menu transaksi yang berfungsi untuk memastikan pesanan penjualan dari pelanggan apakah sudah benar atau belum dan juga apakah penjualan sudah terbayar atau belum.

Bagian penjualan memilih mепи cetak nota kemudian pilih tanggal transaksi untuk nota yang akan di pastikan pesanan penjualannya. Setelah diklik maka akan muncul seperti tampilan pada Gambar 9. Tampilan ini menunjukkan jumlah pesanan yang sudah dibayar sudah dikonfirmasi pembayarannya, jumlah pesanan sudah dibayar belum dikonfirmasi pembayarannya dan jumlah pesanan yang belum dibayar, serta jumlah pesanan dari toko. Cara kerja Sistem Informasi Akuntansi Pembelian ini adalah semua transaksi yang sudah dibayar dan mendapat konfirmasi bayar dari bagian Penjualan dapat direkapitulasi barangnya untuk dipesankan kepada petani.

\section{Sistem Informasi Penjualan \\ Toko Sayur Gamsa \\ JI. Sawi No. 01 RT. 02 RW. 03 Salatiga \\ Telp: (0298) 312345}

Selamat datang, Anda login sebagai Budi

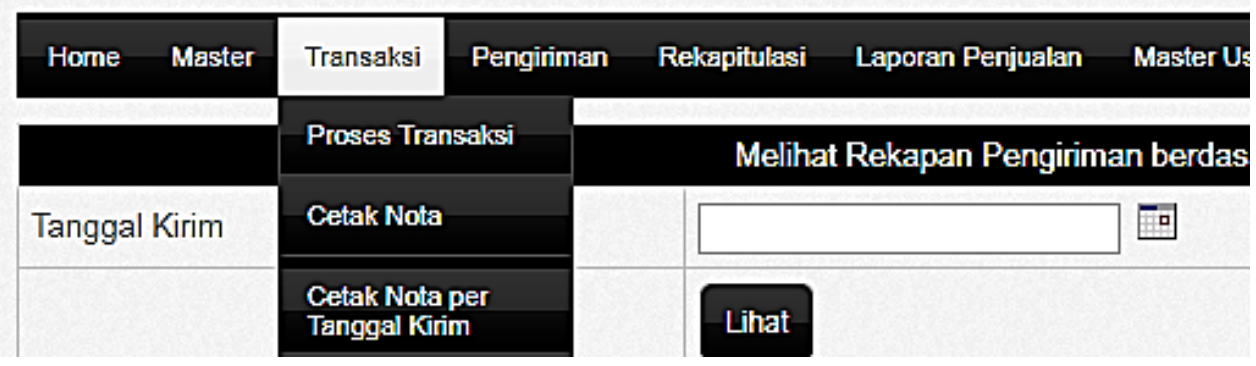

Gambar 8. Menu transaksi penjualan UD XYZ Salatiga

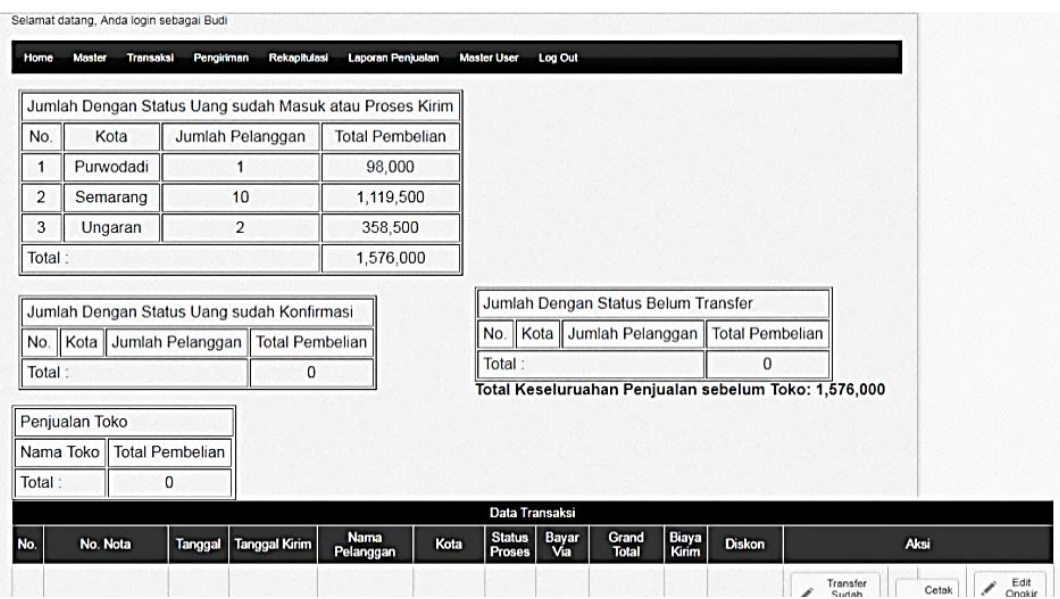

Gambar 9. Tampilan pesanan penjualan UD XYZ Salatiga 
Bagian penjualan melakukan pengecekan terhadap apakah yang dipesan dan juga apakah jumlah uang yang ditransfer sudah benar? Jika sudah benar maka bagian penjualan klik tombol transfer sudah masuk sehingga transaksi akan masuk pada kelompok status uang sudah masuk dan siap proses kirim. Gambar 10. Merupakan tampilan keseluruhan data penjualan pada tanggal tertentu. Pada tampilan ini terdapat fasilitas untuk menandai transaksi sudah terbayar dan uang transfer sudah masuk, menandai barang sudah terkirim, cetak nota, edit ongkir, edit nota, edit deposit, hapus transaksi.

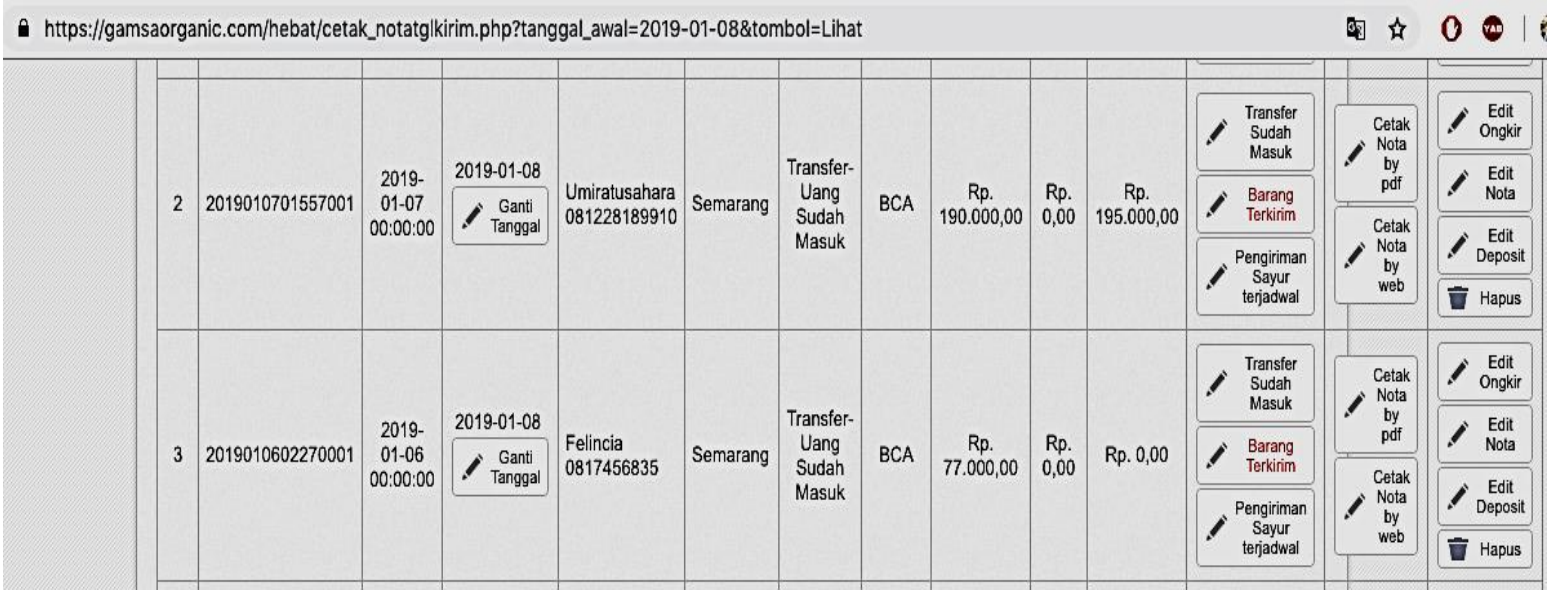

Gambar 10. Tampilan detail pesanan penjualan UD XYZ Salatiga

Langkah berikutnya adalah bagian pembelian melakukan rekapitulasi data pesanan ke petani (aktivitas 2.0). Tampilan Gambar 11 adalah tampilan yang berfungsi untuk melakukan rekapitulasi data pembelian berdasarkan tanggal dikelompokkan berdasarkan barang (menu rekapitulasi/laporan rekap sayur) atau pelanggan (menu rekapitulasi/Laporan Detail Pembelian sayur). Bagian pembelian memilih tanggal pengiriman yang akan direkapitulasi.

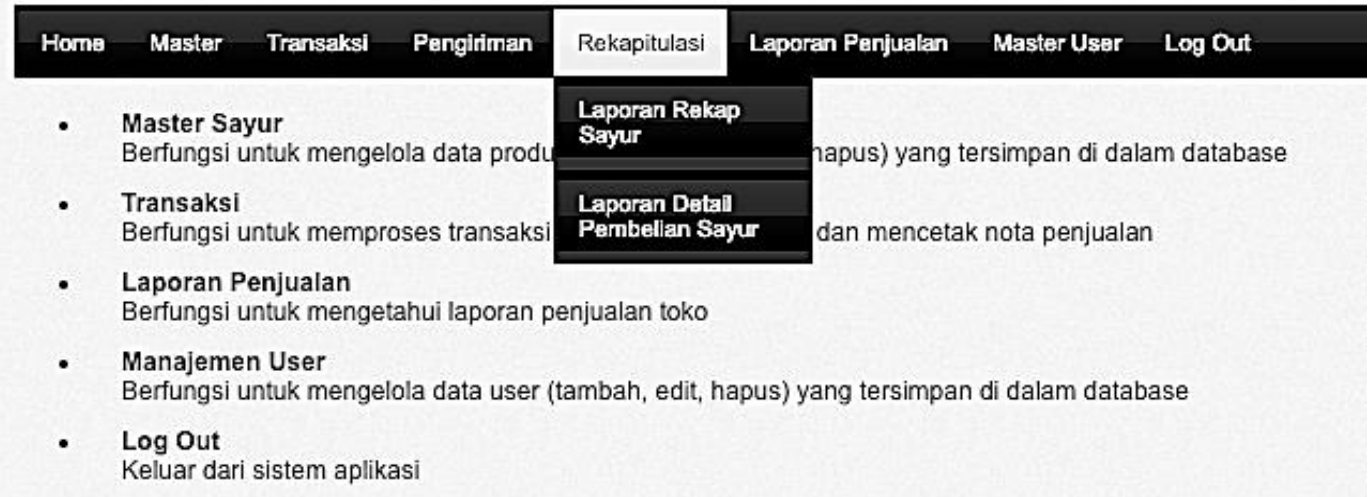

\section{Gambar 11. Tampilan menu Rekapitulasi}

Setelah memilih tanggal maka sistem akan menampilkan tampilan seperti Gambar 12. Sistem menampilkan data barang (dikelompokkan berdasarkan barang) yang akan dipesankan ke petani. Tampilan sistem menampilan data jumlah sayur dan data petani sehingga memudahkan bagian pembelian untuk melakukan pemesanan barang ke petani. Dengan tampilan Gambar 12 bagian pembelian dapat menuliskan rekap pesanan pembelian berdasarkan petani dan memberikan data pesanan kepada petani dengan cepat dan tidak terjadi kesalahan. Gambar 13 merupakan tampilan rekapitulasi pesanan barang berdasarkan pelanggan. 


\begin{tabular}{|c|c|c|c|c|c|c|}
\hline \multicolumn{7}{|c|}{ Horne Master Transaksi Penginiman - } \\
\hline \multicolumn{7}{|c|}{ Data Pelanggan Baru- Untuk Tanggal : 2019-01-08 } \\
\hline No. & Kode Sayur & Jumlah Sayur & Satuan & Nama Sayur & Kategori & Petani \\
\hline 1 & S534 & 1 & 10000 & Beras Mentik Wangi $10 \mathrm{Kg}$ & beras & \\
\hline 2 & S507 & 1 & 6000 & Beras Mentik Wangi $6 \mathrm{Kg}$ & beras & \\
\hline 14 & S537 & 1 & 200 & Arugula & Premium & Pet01 \\
\hline 15 & S690 & 2 & 500 & Zukini & Premium & Pet01 \\
\hline 16 & So07 & 2 & 250 & Bunga Kol & Sayur-Premium & Pet01 \\
\hline 17 & S010 & 1 & 1000 & Kabocha & Sayur-Premium & Pet01 \\
\hline 18 & S564 & 1 & 100 & Korender / Daun Ketumbar & Sayur-Premium & Pet01 \\
\hline 19 & S567 & 2 & 400 & Labu Siam Baby & Sayur-Premium & Pet01 \\
\hline 20 & S578 & 1 & 1000 & Sawi Putih & Sayur-Premium & Pet01 \\
\hline 21 & S584 & 1 & 250 & Selada Iceberg / Lettuce & Sayur-Premium & Pet01 \\
\hline 22 & S598 & 3 & 400 & Tomat & Sayur-Premium & Pet01 \\
\hline 23 & 5600 & 2 & 400 & Wortel & Sayur-Premium & Pet01 \\
\hline 24 & S540 & 2 & 250 & Brokoli & Sayur-Premium & Pet02 \\
\hline 14 & S537 & 1 & 200 & Arugula & Premium & Pet01 \\
\hline 15 & S690 & 2 & 500 & Zukini & Premium & Pet01 \\
\hline 16 & S007 & 2 & 250 & Bunga Kol & Sayur-Premium & Pet01 \\
\hline
\end{tabular}

Gambar 12. Tampilan rekapitulasi pesanan pembelian berdasarkan kelompok barang

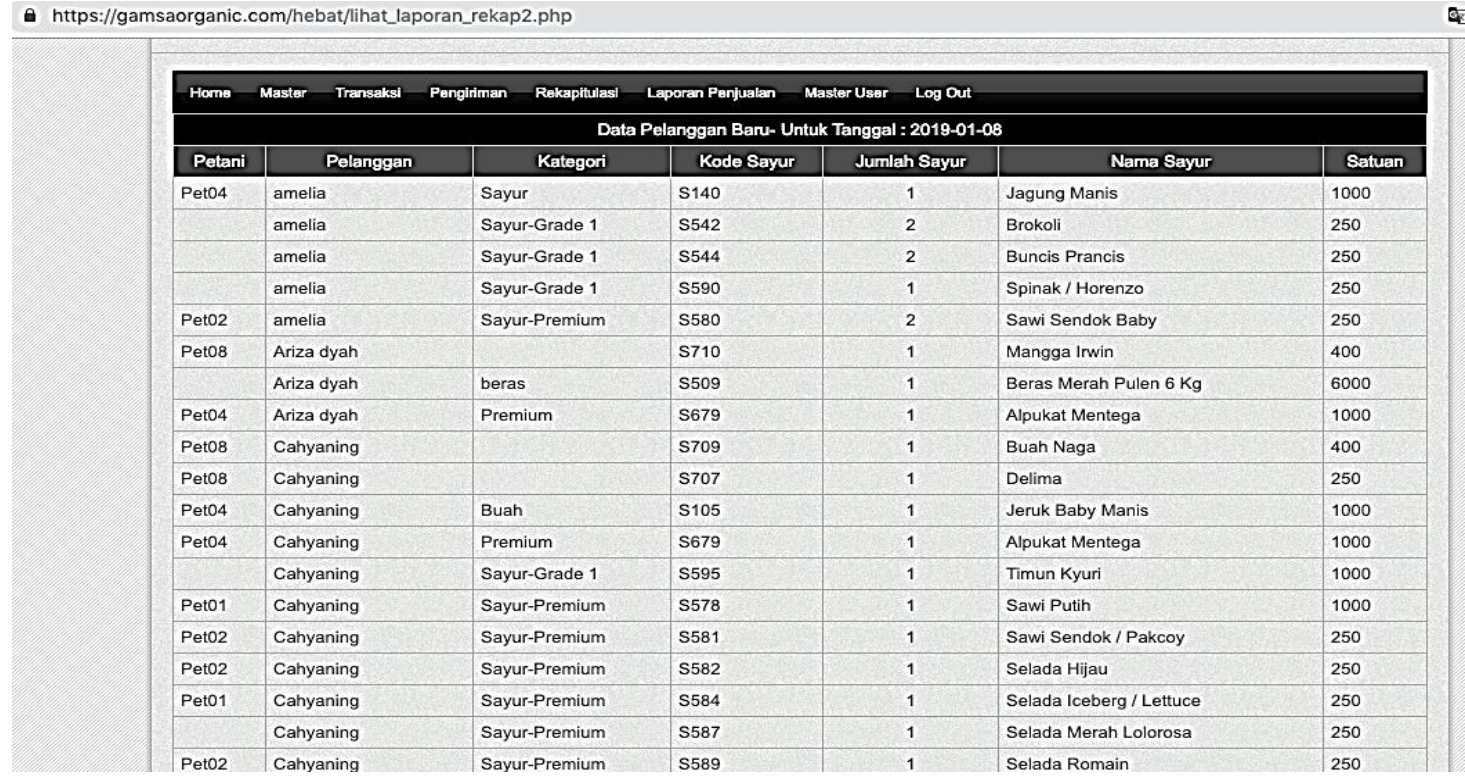

Gambar 13. Tampilan rekapitulasi pesanan pembelian berdasarkan pelanggan

\section{KESIMPULAN DAN SARAN}

\subsection{Kesimpulan}

Dari hasil pembahasan dan analisis mengenai sistem informasi akuntansi pembelian UD XYZ Salatiga dengan tahapan pendefinisian dan analisis kebutuhan, desain sistem informasi menggunakan Data Flow Diagram (DFD), Resouces Events Agent(REA), Rancangan Form serta Implementasi menghasilkan rancangan sistem informasi akuntansi pembelian berupa prosedur transaksi yang berjalan dalam perusahaan, rekomendasi prosedur dengan menggunakan sistem informasi, Rancangan DFD context, Rancangan DFD level 0, Rancangan DFD Level 1, Rancangan REA, Rancangan REA Keybase, Rancangan REA ke dalam database, User Interface antara lain: Pesanan Penjualan ; Detail Pesanan; Rekapitulasi Pesanan. Penerapan sistem informasi akuntansi pembelian terkomputerisasi berbasis web dapat memberikan manfaat dan keuntungan antara lain. 
- Dengan adanya sistem informasi akuntansi pembelian maka rekapitulasi pembelian dapat dibuat tanpa harus menghabiskan banyak waktu.

- $\quad$ Dengan adanya sistem informasi akuntansi pembelian maka hasil rekapitulasi sedikit kesalahan dalam mengelompokkan data barang sesuai dengan petani dan jumlah yang akan dibeli.

\subsection{Saran}

Sistem Informasi Akuntansi Pembelian UD XYZ Salatiga yang dirancang dalam penelitian diatas baru sampai pada bagaimana user dapat melakukan rekapitulasi data pesanan pembelian ke pemasok/petani. Sistem Informasi Akuntansi Pembelian belum dapat memilihkan antara petani yang mempunyai barang dengan harga yang lebih murah sehingga tujuan dari perusahaan terhadap laba dapat tercapai. Maka dari itu untuk penelitian selanjutnya dapat ditambahkan fasilitas dari sitem yang dapat menyediakan perbandingan harga antar petani sehingga dapat dipilih barang dari petani yang mempunyai harganya lebih murah dangan kualitas sama.

\section{DAFTAR PUSTAKA}

Juwitasary, H., Martani, M., \& Putra, A. N. G. (2015). Analisis Sistem Informasi Akuntansi Pembelian dan Persediaan pada PT. XYZ. Comtech, 6(1), 96-108. https://doi.org/https://doi.org/10.21512/comtech.v6i1.2294

Indrajani. (2015). Database Design. Jakarta: Elex Media Komputindo.

Mudjahidin. (2004). Siklus bisnis pada sistem informasi akuntansi. Jurnal Ilmiah Teknologi Informasi, 3(2), 93-100. https://doi.org/10.12962/j24068535.v3i2.a261

Purwoko. (2010). Perancangan Sistem Informasi Akuntansi Pembelian Dan Persediaan. CommIT, 4(1), 68-76. Retrieved from http://journal.binus.ac.id/index.php/commit/article/download/538/516

The Mind Tools Content Team. (2010). Porter's Value Chain - Strategy Skills Training from MindTools.com. Mind Tools. Retrieved from https://www.mindtools.com/pages/article/newSTR_66.htm 